\title{
High-Precision Chronostratigraphic Correlation of Mid-Cretaceous Strata in Western Interior Basin, USA through Graphic Correlation Technique
}

\author{
Fei Shang1, Ruiqian Chen ${ }^{2,3}$, Zehui Zhao', Robert W. Scott ${ }^{4}$, Li Song3 \\ ${ }^{1}$ Research Institute of Petroleum Exploration \& Development, Petrochina, Beijing, China \\ ${ }^{2}$ State Key Laboratory of Petroleum Resources and Prospecting, China University of Petroleum (Beijing), Beijing, China \\ ${ }^{3}$ College of Geosciences, China University of Petroleum (Beijing), Beijing, China \\ ${ }^{4}$ Department of Geosciences, University of Tulsa, Tulsa, USA \\ Email: fshang@petrochina.com.cn
}

How to cite this paper: Shang, F., Chen, R.Q., Zhao, Z.H., Scott, R.W. and Song, L. (2018) High-Precision Chronostratigraphic Correlation of Mid-Cretaceous Strata in Western Interior Basin, USA through Graphic Correlation Technique. Journal of Geoscience and Environment Protection, 6, 266-277.

https://doi.org/10.4236/gep.2018.65023

Received: December 14, 2017

Accepted: May 28, 2018

Published: May 31, 2018

\begin{abstract}
Graphic correlation method has been proved to be very useful in correlating sections in different places. In this study, we have selected five sections from the Western Interior Basin, USA and applied graphic correlation method to correlate them. The selected five sections are located from the eastern to the western margins of the Western Interior Basin, USA. The cross-basinal high-precision chronostratigraphic correlation provides geologists a better understanding about how facies and depositional environments evolved across the mid-Cretaceous Western Interior Basin during the mid-Cretaceous. In addition, our data fits well with the previous understandings about midCretaceous Western Interior Seaway, which characterized by slow depositional rates and higher organic matter concentration.
\end{abstract}

\section{Keywords}

Graphic Correlation, High-Precision Chronostratigraphy, Western Interior Basin, Paleontology

\section{Introduction}

Graphic correlation technique was first developed by Alan Shaw during the late 1950s, as he found that traditional biostratigraphic zonation techniques were often inadequate to solve some stratigraphic problems [1]. Technically, graphic correlation is a quantitative, but non-statistical technique to determine the coev- 
al relationship between two sections by comparing the ranges of fossils in both sections [2]. Petroleum geologists, as well as others, have demonstrated the effectiveness and utilitarian nature of the technique for years. More and more geologists are starting to use graphic correlation technique as the method provides finer precision and resolution of the stratigraphic record than traditional lithostratigraphic correlation [3].

\subsection{Geological Background}

The Western Interior Basin (WIB) of North America was a marine depositional basin developed during mid- to Late Cretaceous (Figure 1) [4] [5]. The basin formed as an Andean-style foreland basin in response to crustal loading in the tectonically active Sevier Orogenic Belt on the western margin of North America [6]. The basin achieved its greatest size during Cenomanian-Turonian time when sea level reached the highest peak during maximum Cretaceous sea-level transgressions [4]. At that time, the basin extended from the Gulf Coast to the Arctic as a northwestern arm of the Caribbean Province of the Tethys Ocean [4], and the sea-level was $300 \mathrm{~m}$ or more higher than present day.

\subsection{Stratigraphy}

Three geological formations were deposited in the Western Interior Basin during mid-Cretaceous. From the bottom to the top, they are the Dakota Sandstone, Graneros Shale and Greenhorn Limestone, respectively.

\section{Dakota Formation}

The Dakota Formation lies unconformably atop Lower Cretaceous, Paleozoic and Precambrian rocks. Deposition of the Dakota Formation began in latest Albian and continued into early Cenomanian [7]. The Dakota Formation is $60 \mathrm{~m}$ to $90 \mathrm{~m}$ in the western half of Kansas and crops out extensively in the central

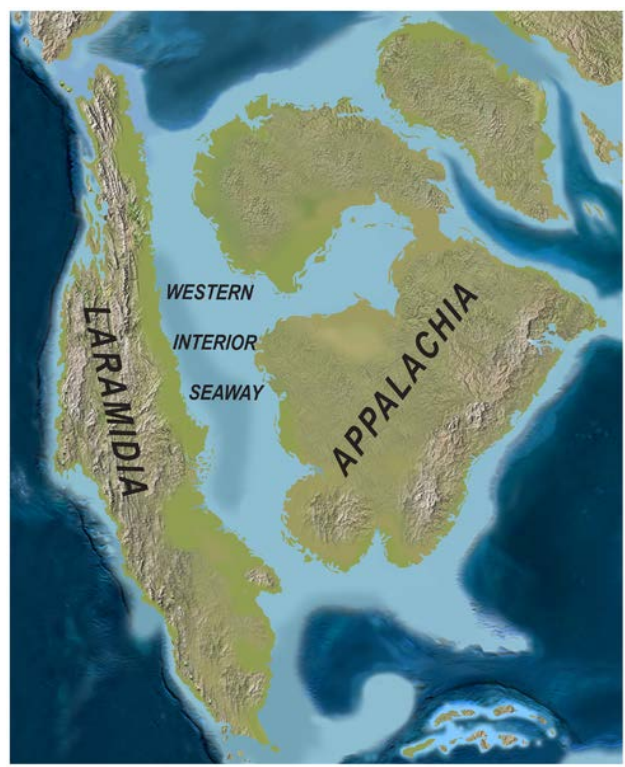

Figure 1. Paleogeography of North America during the mid-Late Cretaceous ( 75 Ma) [5]. 
and north-central part of the state [8], however, only the upper $12 \mathrm{~m}$ of the Dakota Formation is exposed in our field trip area, which is located south of the town of Wilson, Russell county, central Kansas. The Dakota Formation crops out south of Wilson in a strongly weathered hillside surface (Figure 2(a)). The color change from light-gray to dark-gray from bottom up indicates the transition from the non-marine to marginal marine facies of the Dakota Formation to the marine Graneros Formation.

\section{Graneros Shale}

The Graneros Shale was deposited during Middle to Late Cenomanian, and is a generally non-calcareous dark-grey shale formed after the Dakota Formation and before the Greenhorn Limestone. The Graneros Shale was formed non-uniformly in the Western Interior Basin. The contact between Dakota Formation and Graneros Shale is hard to define. From the upper part of the Dakota to the lower part of the Graneros, the lithology changes from complexly varied sandstone and shale interbeds to a more uniform shale formation. The change represents a transition of depositional environment from non-marine and marginal marine environment to full marine conditions [9]. In outcrops, the non-resistant Graneros shale beds are usually badly weathered. One of a few well exposed Graneros section is at Rock Canyon near west of Pueblo, Colorado (Figure 2(b)). It presents as dark-grey hillside. The lower part of the Graneros is generally composed of dark-grey noncalcareous shale. The upper part of the Graneros is composed of dark grey silty shale that commonly includes several thin beds of calcareous sandstone in the lower part and thin beds of skeletal limestone in the upper part. The calcium carbonate content increases from the lower part to upper part suggesting that salinity increased progressively as Graneros deposition proceeded. The contact between Graneros Shale and Greenhorn

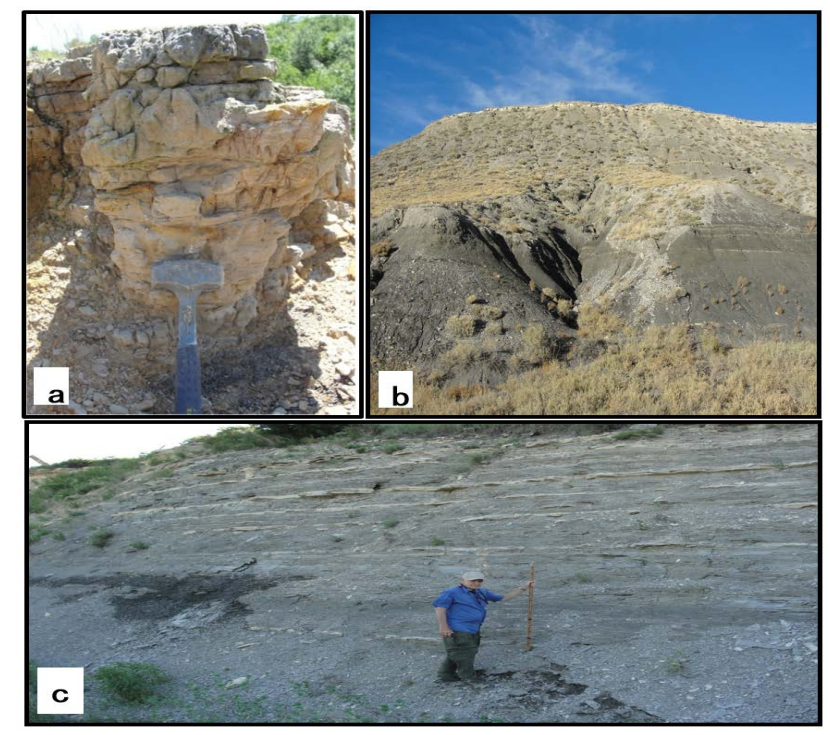

Figure 2. (a) Dakota sandstone exposed to the south of the town of Wilson, Russell county, central Kansas; (b) Graneros shale exposed at Rock Canyon near west of Pueblo, Colorado; (c) Exposure of the Greenhorn Formation at Bunker Hill Section, central Kansas. 
Limestone is mostly comformable in the Western Interior Basin [9]. But the thickness of the Graneros changes greatly. It is about $34 \mathrm{~m}$ thick in Pueblo, Colorado and decreases to about $9 \mathrm{~m}$ thick on average in central Kansas.

\section{Greenhorn Limestone}

The Greenhorn Limestone was formed during one of the most extensive transgressive episodes in the Western Interior Seaway during the mid-Cretaceous [10]. It usually contains three members which are from the bottom to the top, the Lincoln Limestone, the Hartland Shale, and the Bridge Creek Limestone. In eastern Kansas, the Bridge Creek Limestone is further divided into Jetmore Member and Pfeifer Member. The lower and middle parts of the Greenhorn mainly consist of calcareous shale and its upper part mainly consists of thin limestone and shale interbeds. In this study, we visited Greenhorn sections at Bunker Hill, Kansas and Rock Canyon, Colorado (Figure 2(c)). The Greenhorn Limestone is about $46 \mathrm{~m}$ thick in Rock Canyon and about $24 \mathrm{~m}$ thick in central Kansas. The Lincoln Member is the lowermost member of Greenhorn Limestone. It is about $6 \mathrm{~m}$ to $12 \mathrm{~m}$ in thickness and mainly consists of calcareous shale with one or more thick hard beds of calcarenite. The Hartland Shale Member, which over lays the Lincoln Member, is composed of well-laminated, organic-rich shale deposited during a sea-level rise event in the Late Cenomanian.

\section{Data and Methodology}

We have applied the graphic correlation technique to conduct high-precision chronostratigraphic correlation for the five stratigraphic sections we studied in Colorado, Kansa and Arizona (Figure 3).

\subsection{Lithostratigraphic Data}

Five outcrop sections and cores in the Western Interior were used. From east to west, they are: Bunker Hill section; Amoco No.1 Rebecca K. Bounds Core; Pueblo section; Mesa Verde section, and Black Mesa section (Figure 3).

The Bunker Hill section is located in the Russell County in the middle of Kansas. The section is $67 \mathrm{~m}$ in thick. From the bottom to the top, it contains the upper part of the Graneros Shale, Greenhorn Limestone and lower part of the Carlile Formation as described in the "Introduction".

The Amoco No.1 Rebecca K. Bounds Core is located in the center of the Western Interior Basin. It is $305 \mathrm{~m}$ in length and cuts a complete Albian to Santonian section. The core is very important for it serves as a key reference section for Cretaceous strata in the middle of the WIS [11]. It provides high-resolution data for high-precision quantitative stratigraphic correlations.

The Pueblo section is located in Lake Pueblo State Park, central Colorado. The section is about $20 \mathrm{~m}$ thick and mainly exposes the Bridge Creek Limestone. It is a GSSP section which defines the base of Turonian. The age of the base Turonian has been recently changed to $93.3 \mathrm{Ma}$ [12]. In the CRET1 Database, the base is at 93.0 Ma, which is within the error bar of the radiometric ages of the 


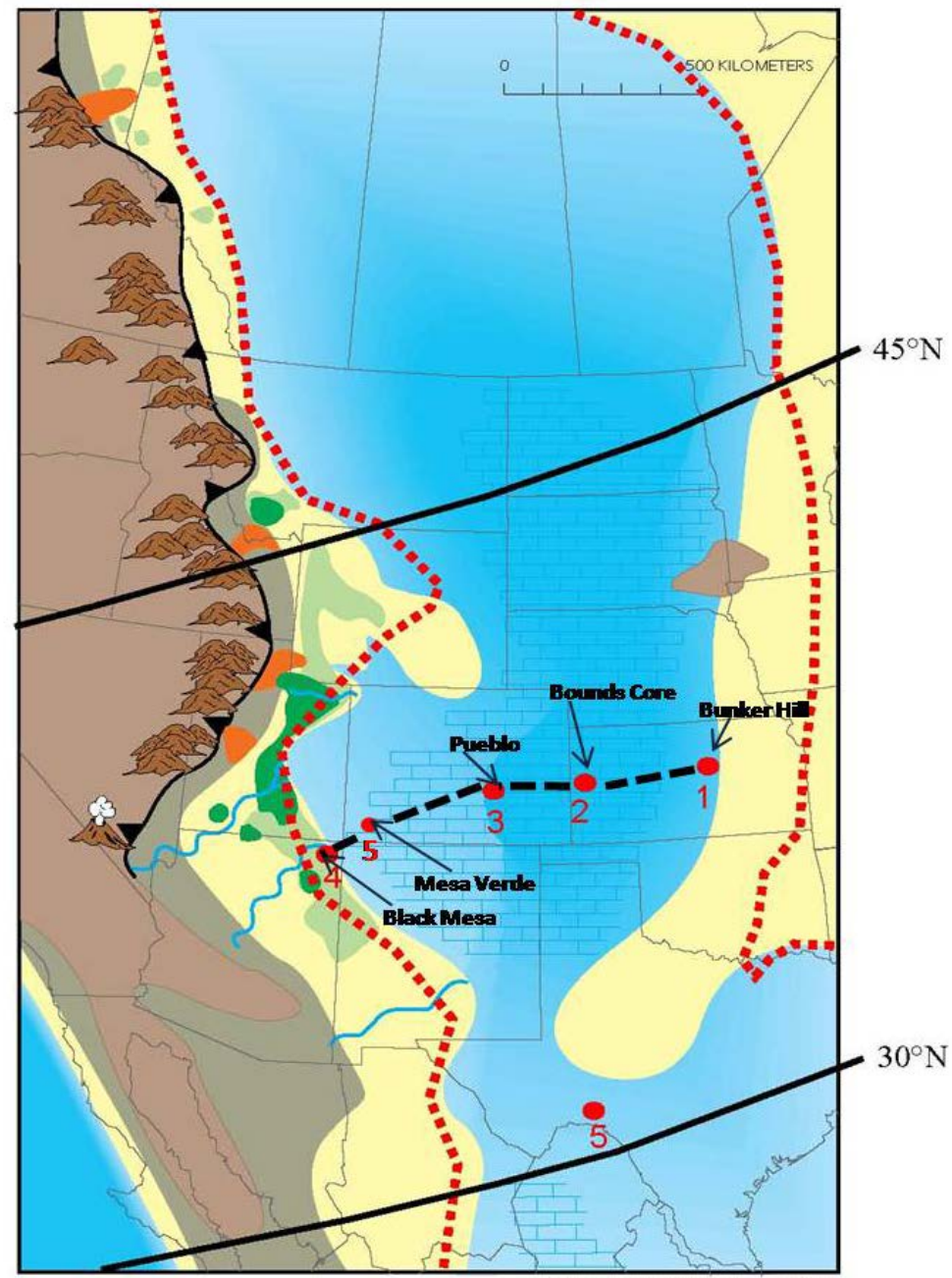

Figure 3. Paleogeographic map of the Western Interior Basin. The dashed red-lines represent inferred coastlines proposed by Sageman et al. (1998) [14]. The black solid lines represent paleolatitudes. Numbers refer to locations of core and measured sections which will be studied in the research. 1. Bunker Hill section; 2. The Amoco No.1 Bounds Core; 3. Pueblo section; 4. Black Mesa section; 5. Mesa Verde section.

associated bentonites [13].

The Mesa Verde section has been chosen as the key reference section for our study. The section has been studied and described with in detail through the 628 $\mathrm{m}$ formation. The Mesa Verde section is composed of seven units. In ascending order, they are Graneros, Bridge Creek Limestone, Fairport, Blue Hill, Juana Lopez, Montezuma Valley, and Smoky Hill members.

The Graneros Member is a dark-grey sandy mudstone and silty shale in the lower $10 \mathrm{~m}$, and a slightly silty calcareous shale in the upper $14.1 \mathrm{~m}$. The Graneros Member of the Mancos Shale at Mesa Verde ranges from upper Cenomanian Metoicoceras mosbyensis zone to the Cenomanian/Turonian boundary. Accordingly, the Graneros Member correlates to the middle and upper parts of the Hartland Shale Member and lower part of the Bridge Creek Limestone Member of the Greenhorn Limestone along the Colorado Front Range [14] [15]. 
The lower $3.7 \mathrm{~m}$ of the Bridge Creek Limestone Member is composed of interbedded limestone and calcareous shale, and its upper $10.1 \mathrm{~m}$ changes to interbeded calcarenite, shaly limestone and calcareous shale. The faunal data and marker-bed correlation indicates that the Bridge Creek Limestone Member contains a relatively continuous stratigraphic record extending from the basal Turonian Pseudaspidoceras flexuosum Zone to the Woollgari woollgari-Mytiloides hercynicus Zone [16].

The Fairport Member is composed of fossiliferous calcareous shale which contains numerous limonite seams, bentonite seams, and bentonite beds. A regional disconformity at the Fairport-Blue Hill boundary is suggested by abrupt lithologic change from calcareous to non-calcareous shale [16]. Evidence of seafloor erosion is suggested by the presence of calcisilt streaks defining the lamination in the upper $5 \mathrm{~m}$ of the Fairport and a lag of broken juvenile ammonite shells and oysters along a bedding plane in the basal meter of the Blue Hill Member.

The Blue Hill Member is a dark grey, non-calcareous, poorly fossiliferous shale to silty shale that contains widely scattered concretions. The lower $15.5 \mathrm{~m}$ of the member mainly consists of shale and scattered concretions. The upper 56 $\mathrm{m}$ of the member consists of silty shale with occasional thin siltstone beds. Two thin bentonite beds at $73.8 \mathrm{~m}$ and $79.3 \mathrm{~m}$ have the characteristics that also observed at the type locality of the Blue Hill Member of the Carlile Shale in Kansas [9] [16].

The Juana Lopez Member is a dark, non-calcareous, slightly silty to silty shale that contains numerous beds of orange-weathering calcarenite. The member at Mesa Verde extends from the lower upper Turonian Prionocyclus macombi Zone into the upper Turonian Scaphites whitfieldi Zone [16].

The Montezuma Valley Member is silty calcareous shale that contains numerous septarian concretions. The member ranges from within the upper Turonian Scaphites whitfieldi Zone upward into the uppermost Turonian Prionocyclus quadratus Zone. The uppermost Turonian and lower Coniacian rocks are missing in the sharp shale-on-shale disconformity between the Montezuma Valley Member and the overlying Smoky Hill Member [16].

The Smoky Hill Member is composed of dark-grey, well-laminated calcareous shale, mudstone, and marlstone. The lower contact of the Smoky Hill Member corresponds with a wide-spread disconformity separating Carlile rocks below and Niobrara rocks above. The amount of the time represented by the disconformity can be estimated based on fossil records in the underlying Montezuma Valley Member and the lowermost age-determination fossils within the Smoky Hill [16]. Generally, the entire Smoky Hill Member at Mesa Verde spans the upper Coniacian through middle Santonian [16].

\subsection{Biostratigraphy Data}

The biostratigraphic data is based mainly on molluscan fossil record of the cen- 
tral and northern parts of the Western Interior of the United States [17]. These records mainly include ammonite and inoceramid zonation, as well as radiometric ages of bentonites [12]. A USGS zonal chart for the Upper Cretaceous Middle Cenomanian-Maastrichtian of the Western Interior of the United States based on ammonites, inoceramids, and radiometric ages [17] gives us the fundamental biostratigraphy information (Figure 4). Nearly one-half of the inoceramid zones and some of the ammonite zones and are known in Europe. A few of the ammonite zones are known from only a few localities, but the diagnostic species may occur in abundance [17]. This zonation is based on field work by U.S. Geological Survey geologists and geologists outside the USGS, especially the works of Kauffman and associates [4] [17].

\subsection{Chronostratigraphic Database Selection}

The chronostratigraphic database we used came from the Standard Composite of "CRET1 Chronostratigraphic Database" [13]. The database is a compilation of more than 3400 fossil taxa and marker beds from numerous published worldwide sections that span from the Jurassic/Cretaceous boundary to the Cretaceous/Paleogene boundary [13]. The composite standard of the Database has been scaled from thickness to numerical ages by graphic correlation [13]. By using the graphic correlation technique, we can correlate the composite standard with a global chronostratigraphic scale. This method enables us to project the positions of Cretaceous stages and substages into the Bunker Hill Section. A detailed description of the graphic correlation method can be found in [3].

\section{Results and Discussion}

\subsection{Line of Correction (LOC)}

The line of correlation (LOC) needs to be established before conducting graphic correlation. In this study, we generated the LOC using the chronostratigraphic data from Bunker Hill Section. As shown in Figure 5, the LOC can be divided into three segments with different slopes. From the bottom to the top of the section, the slope of LOC first decreases and then increases. As the slopes of LOC represent rates of rock accumulation, we can conclude that the Lincoln and Pfeifer members had higher rock accumulation rates than that of the Hartland and Jetmore members. By plotting the bases of each Greenhorn member horizontally onto the LOC, then plotting the points on LOC vertically onto $\mathrm{X}$-axis, the numerical ages for each boundary can be calculated:

1) The age of the base of Lincoln Limestone Member is $93.7 \mathrm{Ma}$;

2) The age of the base of Hartland Shale Member is $93.4 \mathrm{Ma}$;

3) The age of the base of Jetmore Member is $92.9 \mathrm{Ma}$;

4) The age of the base of Pfeifer Member is $92.5 \mathrm{Ma}$;

5) The age of the top of Pfeifer Member is 92.2 Ma.

Rock accumulation rates for each Greenhorn member can be calculated based on these data: Lincoln Limestone Member (21.64 m/Ma); Hartland Shale Member 
William A. Cobban, John D. Obradovich, Ireneusz Walaszcyk, and Kevin C. McKinney

\begin{tabular}{|c|c|c|c|c|c|c|}
\hline \multicolumn{3}{|c|}{$\begin{array}{c}\text { Stages and } \\
\text { Substages }\end{array}$} & \multirow{4}{*}{$\begin{array}{c}\text { 2Stage } \\
\text { Boundaries } \\
\text { Ma } \\
{ }^{9} 65.5 \pm 0.30\end{array}$} & $\begin{array}{l}\text { Western Interior Ammonite } \\
\text { Taxon Range Zones }\end{array}$ & $\begin{array}{l}\text { Age } \\
\mathrm{Ma}\end{array}$ & $\begin{array}{c}\text { Western Interior } \\
\text { Inoceramid Interval Zones }\end{array}$ \\
\hline \multirow{6}{*}{ 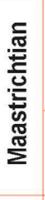 } & \multirow{3}{*}{\multicolumn{2}{|c|}{ Upper }} & & Jeletzkytes nebrascensis & & \\
\hline & & & & Hoploscaphites nicolletii & & \\
\hline & & & & Hoploscaphites birkelundae & & \\
\hline & \multirow{3}{*}{\multicolumn{2}{|c|}{ Lower }} & \multirow{12}{*}{$70.6 \pm 0.6$} & Baculites clinolobatus & $69.59 \pm 0.36$ & "Inoceramus" balchii \\
\hline & & & & Baculites grandis & $70.00 \pm 0.45$ & Trochoceramus radiosus \\
\hline & & & & Baculites baculus & & $\begin{array}{l}\text { "Inoceramus" incurvus } \\
\text { Endocostea typica }\end{array}$ \\
\hline \multirow{23}{*}{ 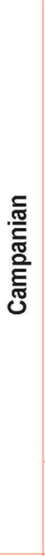 } & \multirow{10}{*}{ 'Europe } & \multirow{9}{*}{$\begin{array}{c}\begin{array}{c}\text { Western } \\
\text { Interior } \\
\text { Informal } \\
\text { Substages }\end{array} \\
\text { Upper }\end{array}$} & & Baculites eliasi & $71.98 \pm 0.31$ & "Inoceramus" redbirdensis \\
\hline & & & & Baculites jenseni & & \multirow{2}{*}{ "Inoceramus" oblongus } \\
\hline & & & & Baculites reesidei & ${ }^{11} 72.94 \pm 0.45$ & \\
\hline & & & & Baculites cuneatus & & \multirow{3}{*}{ "Inoceramus" altus } \\
\hline & & & & Baculites compressus & ${ }^{8} 73.52 \pm 0.39$ & \\
\hline & & & & Didymoceras cheyennense & $74.67 \pm 0.15$ & \\
\hline & & & & Exiteloceras jenneyi & ${ }^{8} 75.08 \pm 0.11$ & \\
\hline & & & & Didymoceras stevensoni & & Sphaeroceramus pertenuiformis \\
\hline & & & & Didymoceras nebrascense & $75.19 \pm 0.28$ & \\
\hline & & & & Baculites scotti & $\begin{array}{r}{ }^{10} 75.56 \pm 0.11 \\
75.84 \pm 0.26\end{array}$ & "Inoceramus" tenuilineatus \\
\hline & \multirow{9}{*}{ Upper } & & & Baculites reduncus & & \\
\hline & & & & Baculites gregoryensis & & \\
\hline & & & & Baculites perplexus & & \\
\hline & & Middle & & Baculites sp. (smooth) & & Cataceramus subcompressus \\
\hline & & Tilucie & & Baculites asperiformis & & \\
\hline & & & & Baculites maclearni & & \\
\hline & & & & Baculites obtusus & ${ }^{8} 80.58 \pm 0.55$ & "Inoceramus" azerbaydjanensis \\
\hline & & & & Baculites sp. (weak flank ribs) & & \\
\hline & & & & Baculites sp. (smooth) & & \\
\hline & & & & Scaphites hippocrepis III & & \\
\hline & Lower & Lower & & Scaphites hippocrepis II & $81.86 \pm 0.36$ & Cataceramus batticus \\
\hline & Lower & & & Scaphites hippocrepis I & & \\
\hline & & & $83.5+0.7$ & Scaphites leei III & & \\
\hline & & & $83.5 \pm 0.7$ & Desmoscaphites bassleri & $884.30 \pm 0.34$ & sphenoceramus lundbreckensis \\
\hline$\cdot \frac{\pi}{E}$ & Upr & per & & Desmoscaphites erdmanni & & \\
\hline$\stackrel{\bar{Z}}{=}$ & & & & ${ }^{7}$ Clioscaphites choteauensis & & Cordiceramus bueltenensis \\
\hline స్ స్ & Mid & dle & & ${ }^{7}$ Clioscaphites vermiformis & & \\
\hline & Lov & & $85.8 \pm 0.7$ & ${ }^{7}$ Clioscaphites saxitonianus & & Cladoceramus undulatoplicatus \\
\hline & Upr & per & $00.0 \pm 0.1$ & ${ }^{6}$ scaphites depressus & $87.14 \pm 0.39$ & $\begin{array}{l}\text { Magadiceramus crenelatus } \\
\text { Magadiceramus subquadratus }\end{array}$ \\
\hline 焉 & Mid & dle & & ${ }^{5}$ Scaphites ventricosus & & $\begin{array}{l}\text { Wolviceramus involutus } \\
\text { Volviceramus koeneni }\end{array}$ \\
\hline 哭 & Low & & & ${ }^{5}$ scaphites preventricosus & $88.55 \pm 0.59$ & $\begin{array}{l}\text { Colviceramus koeneni } \\
\text { Cremnoceramus crassus crassus } \\
\text { Cremnoceramus crassus inconstans } \\
\text { Cremnoceramus deformis dobrogensis } \\
\text { Cremomis deformis erectus }\end{array}$ \\
\hline & & & $89.3 \pm 1.0$ & Scaphites mariasensis & & Cremnoceramus waltersdorfensis \\
\hline & & & & Prionocyclus germari & & Mytiloides scupini \\
\hline & Upp & & & ${ }^{5}$ Scaphites nigricollensis & & Mytiloides incertus \\
\hline & & & & ${ }^{4}$ Scaphites whitfieldi & & $\begin{array}{l}\text { Inoceramus dakotensis } \\
\text { Inoceramus perplexus }\end{array}$ \\
\hline & & & & ${ }^{4}$ Scaphites ferronensis & & Inoceramus dimidius \\
\hline .్ㅡㄹ & & & & $\begin{array}{l}{ }^{4} \text { scaphites warreni } \\
\text { Prionocyclus macombi }\end{array}$ & $90.21 \pm 0.54$ & Inoceramus aff. dimidius \\
\hline ธิ & Mid & dle & & Prionocyclus hyatti & & Inoceramus aff. dimidius \\
\hline 站 & & & & $\begin{array}{l}\text { Prionocyclus hyatti } \\
\text { Collignoniceras praecox }\end{array}$ & $92.46 \pm 0.58$ & Inoceramus howelli \\
\hline & & & & & & Inoceramus n.sp. \\
\hline & & & & Collignoniceras woollgari & & $\begin{array}{l}\text { Mytiolodes hercynicus } \\
\text { Mytiolides subhercynicus }\end{array}$ \\
\hline & & & & Mammites nodosoides & & Mytiloides mytiloides \\
\hline & & & & Vascoceras birchbyi & $93.48 \pm 0.58$ & Mytiloides kossmati \\
\hline & Low & & & Pseudaspidoceras flexuosum & $93.19 \pm 0.42$ & Mytilordes kossmati \\
\hline & & & & Watinoceras devonense & & Mytiloides puebloensis \\
\hline & & & $93.5 \pm 0.3$ & Nigericeras scotti & & Mytiloides hattini \\
\hline & & & & Neocardioceras juddii & $\begin{array}{l}93.32 \pm 0.38 \\
93.82 \pm 0.30\end{array}$ & \\
\hline & & & & Burroceras clydense & & Inoceramus pictus \\
\hline & & & & Euomphaloceras septemseriatum & $93.68 \pm 0.50$ & \\
\hline & Upp & per & & Vascoceras diartianum & $93.99 \pm 0.72$ & \\
\hline & & & & Dunveganoceras conditum & & \\
\hline$\stackrel{\underline{\pi}}{\Xi}$ & & & & Dunveganoceras albertense & & Inoceramus ginterensis \\
\hline$\overline{\bar{\Xi}}$ & & & & Dunveganoceras problematicum & & \\
\hline 흐 & & & & Dunveganoceras pondi & $94.71 \pm 0.49$ & Inoceramus prefragilis \\
\hline 气্ & & & & Plesiacanthoceras wyomingense & & \\
\hline J & & & & ${ }^{3}$ Acanthoceras amphibolum & $94.96 \pm 0.50$ & $\begin{array}{l}\text { Inoceramus rutherfordi } \\
\text { Inoceramus anvanus }\end{array}$ \\
\hline & Midc & dle & & $\begin{array}{l}{ }^{3} \text { Acanthoceras bellense } \\
{ }^{3} \text { Acanthoceras muldoonense }\end{array}$ & & Inoceramus arvanus \\
\hline & & & & $\begin{array}{l}\text { Acanthoceras muldoonense } \\
{ }^{3} \text { Acanthoceras granerosense }\end{array}$ & & Inoceramus macconnelli \\
\hline & & & & Conlinoceras tarrantense & $95.73 \pm 0.61$ & \\
\hline & Low & & & & ${ }^{12} 99.33 \pm 0.37$ & \\
\hline & $\begin{array}{l}1 \text { Two-fold } \\
\text { of Campan } \\
\text { generally a } \\
\text { in Europe }\end{array}$ & $\begin{array}{l}\text { d divisions } \\
\text { nian } \\
\text { accepted }\end{array}$ & $\begin{array}{l}2 \text { Gradstein } \\
\text { and Ogg, } 2004\end{array}$ & $\begin{array}{l}7 \text { Billcobbanoceras of Cooper, } 1994 \\
6 \text { Clioscaahites of Cooper, } 1994 \\
5 \text { Anascaphites of Cooper, } 1994 \\
4 \text { Coloradoscaphites of Cooper, } 1994 \\
3 \text { Texacanthoceras of Cooper, } 1998\end{array}$ & 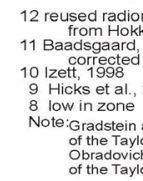 & 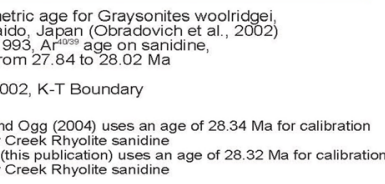 \\
\hline
\end{tabular}

Figure 4. USGS Zonal chart for the Upper Cretaceous Middle Cenomanian-Maastrichtian of the Western Interior of the United States Based on Ammonites, Inoceramids, and Radiometric Ages [17]. 


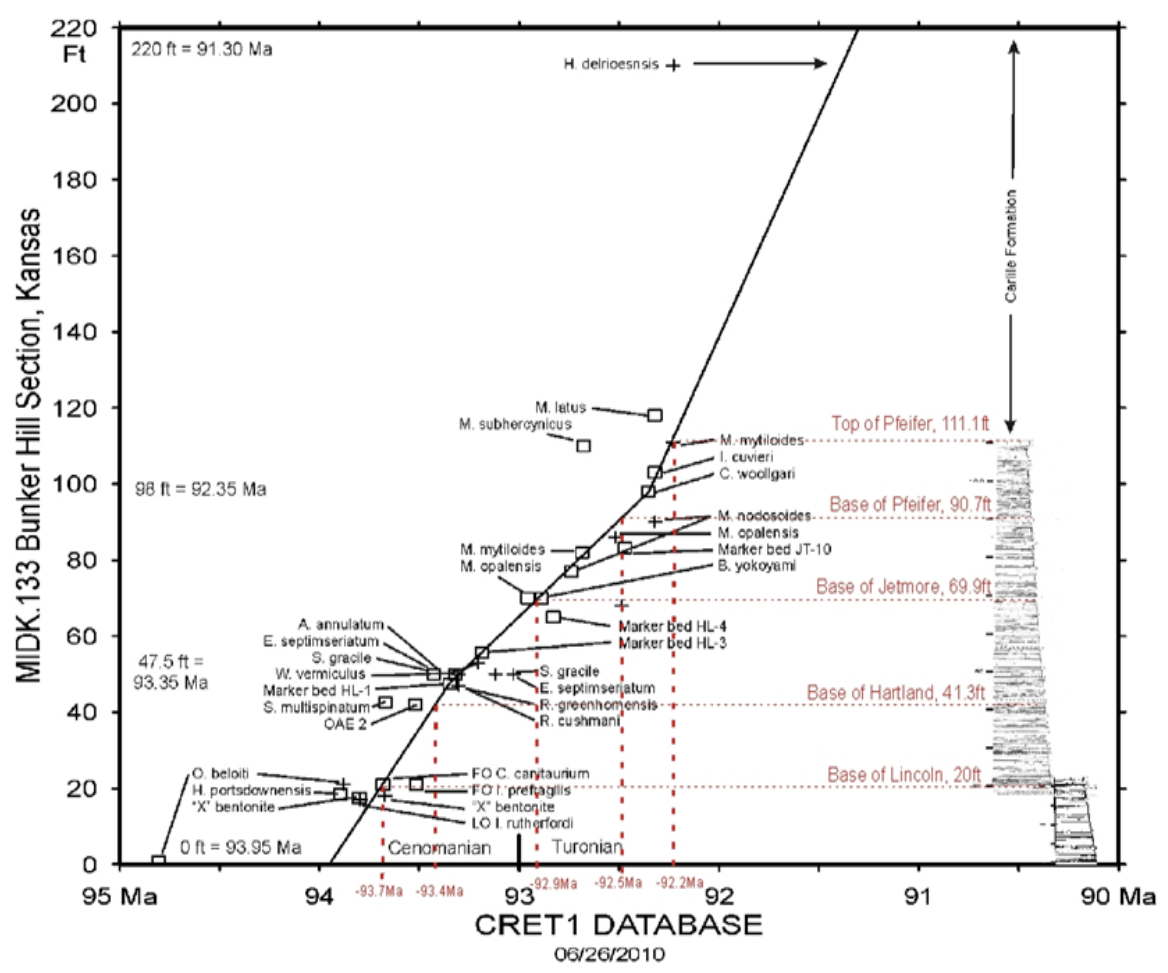

Figure 5. Graphic Correction of the Bunker Hill Section, Russell County, Kansas.

(17.43 m/Ma); Jetmore Member (15.85 m/Ma); Pfeifer Member (20.73 m/Ma). The calculated results show that the rock accumulation rates became slower during the deposition of Hartland and Jetmore members. If we assume there are no significant erosional unconformities present within the Bunker Hill Section, then our data fits well with the previous understandings about Cenomanian/ Turonian Western Interior Seaway, which characterized by slow depositional rates and higher organic matter concentration [4].

\subsection{Cross-Basinal Chronostratigraphic Correlation}

Figure 6 shows the result of the cross-basinal chronostratigraphic correlation in Western Interior Basin. From the west to the east, the middle part of the Lower Shale Members of the Mancos Shale Formation at the Black Mesa changes to Bridge Creek Limestone in both central and eastern part of the basin. The Hopi Sandy Member in the Black Mesa Section changes to silty shale in the lower part of the Blue Hill Member at Mesa Verde. The lower part of the Blue Hill Member at Mesa Verde then correlates with the entire part of the Blue Hill Members at Pueblo and Greeley County, Kansas.

The Upper Mancos Shale Member at Black Mesa correlates with the upper Blue Hill Member at Mesa Verde, and then it changes to Codell Sandstone in the eastern part of the basin. The Juana Lopez Member at Mesa Verde Section thinning to the east. The thickness of the member changes from $40 \mathrm{~m}$ in Mesa Verde Section to $0.5 \mathrm{~m}$ in Pueblo Section, and disappears in Bounds Core. The Toreva Sandstone in Black Mesa Section changes to Montezuma Valley Shale in Mesa 


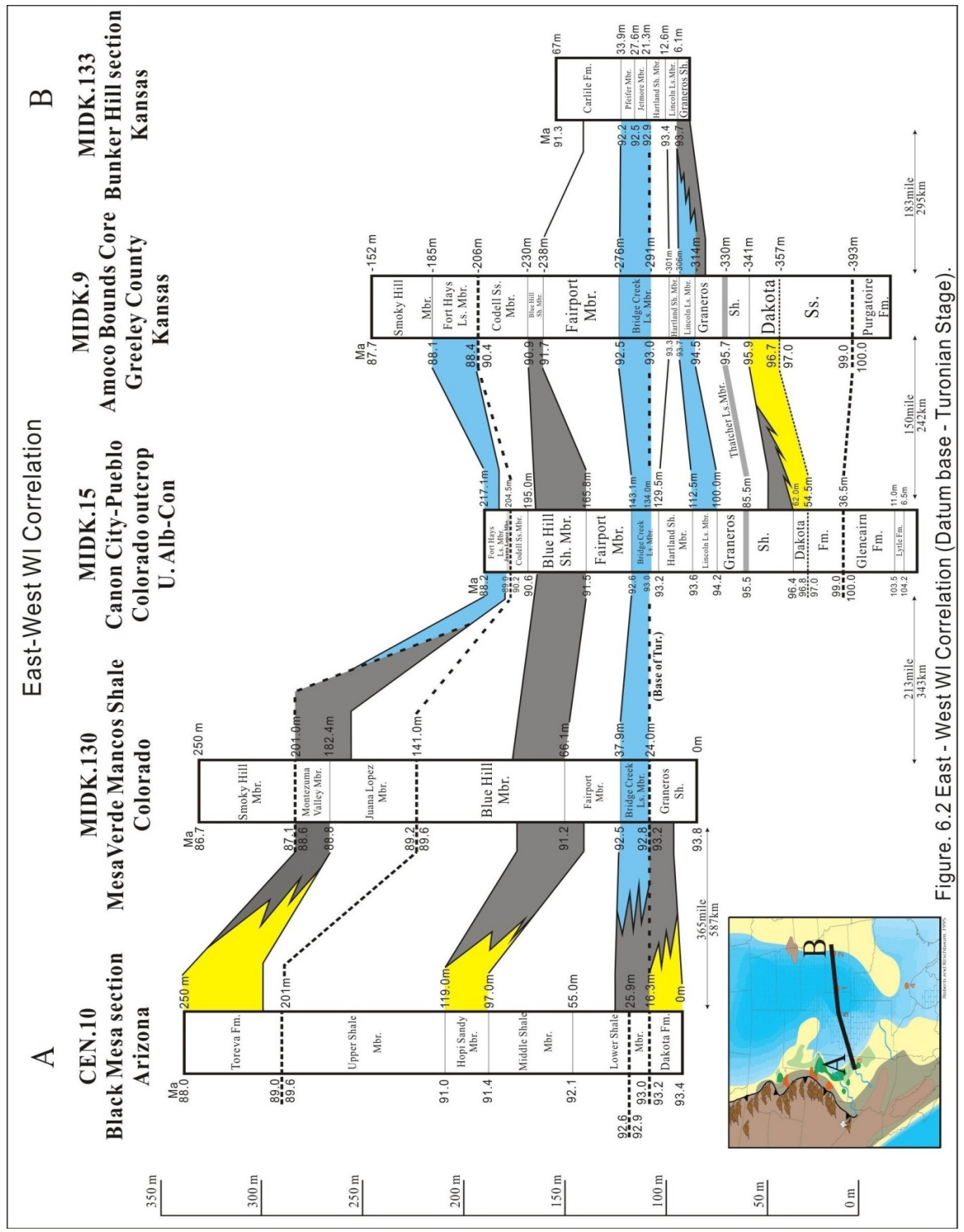

Figure 6. High-precision Chronostratigraphic Correlation of mid-Cretaceous Strata in Western Interior Baisn, USA using Graphic Correlation Technique.

Verde Section, and then the Montezuma Valley Shale changes to Fort Hays Limestone in the central and eastern parts of the basin. The Graneros Shale in the central part of the basin is older than the Graneros formed in the eastern margin of the basin. The Thatcher Limestone found in Bounds Core and Pueblo Section can be correlated together successfully. They were formed at about the same age.

There is a regional unconformity that can be traced around the WI basin. The unconformity represents about $0.6 \sim 1.0$ million years time of non-deposition, and is generally found below the Blue Hill Member and Codell Sandstone.

\section{Acknowledgements}

It is a pleasure to thank the many people who made the study possible, including Dr. Peter Michael, Dr. Bryan Tapp, Dr. Jingyi Chen, Dr. Michael Formolo, Dr. 
Dennis Kerr, and Dr. Kumar Ramachandran for the basic knowledge and insightful comments they provided.

\section{References}

[1] Shaw, A.B. (1964) Time in Stratigraphy. McGraw-Hill, New York, 365 p.

[2] Scott, R.W., Combes, J.M. and Nissen, S.E. (1998) High-Precision Chronostratigraphy of a Late Pleistocene Shelf-Edge Delta, Louisiana. Journal of Sedimentary Research, 68, 596-602. https://doi.org/10.2110/jsr.68.596

[3] Mann, K.O. and Lane, H.R. (1995) Graphic Correlation: SEPM Society for Sedimentary Geology Special Publication No. 53, 263. https://doi.org/10.2110/pec.95.53

[4] Kauffman, E.G. and Caldwell, W.E. (1993) The Western Interior Basin in Space and Time. In: Caldwell, W.E. and Kauffman, E.G., Eds., Evolution of the Western Interior Basin, Spec. Pap.-Geol. Assoc. Can., Vol. 39, 1-30.

[5] Blakey, R.C. (2009) Regional Paleogeography. Northern Arizona University. http://jan.ucc.nau.edu/ rcb7/regionaltext.html

[6] Jordan, T.E. (1981) Thrust Loads and Foreland Basin Evolution, Cretaceous, Western United States. American Association of Petroleum Geologists Bulletin, 65, 2506-2520.

[7] Franks, P.C. (1975) The Transgressive-Regressive Sequence of the Cretaceous Cheyenne, Kiowa, and Dakota Formations of Kansas. In: Caldwell, W.G.E., Ed., The Cretaceous System in the Western Interior of North America, Geological Association of Canada Special Paper, Vol. 13, 469-521.

[8] Hattin, E.D. and Siemers, T.C. (1978) Road Log for April 13, 1977, Kansas Geological Survey, Guidebook 3.

[9] Hattin, D.E. (1965) Upper Cretaceous Stratigraphy, Paleontology, and Paleoecology of Western Kansas. Geol. Soc. America, Field Conf. Guidebook, Ann. Mtg., Kansas City, Mo., 66 p.

[10] Slingerland, R.L. and Kump, L.R. (1996) Estuarine Circulation in the Turonian Western Interior Seaway of North America. Geological Society of America Bulletin, 108, 941-952. https://doi.org/10.1130/0016-7606(1996)108<0941:ECITTW >2.3.CO;2

[11] Scott, R.W., Franks, P.C., Stein, J.A., Bergen, J.A. and Evetts, M.J. (1994) Graphic Correlation Tests the Synchronous Mid-Cretaceous Depositional Cycles: Western Interior and Gulf Coast. In: Dolson, J.C., Hendricks, M.L. and Westcott, W.A., Eds., Unconformity-Related Hydrocarbons in Sedimentary Sequences. Denver, Colorado, Rocky Mountain Association of Geologists, 89-98.

[12] Obradovich, J.D. (1993) A Cretaceous Time Scale. In: Caldwell, W.G.E. and Kauffman, E.G., Eds., Evolution of the Western Interior Basin, Geologic Association of Canada, Special Paper 39, 379-396.

[13] Scott, R.W. (2009) Introduction to the CRET1 Chronostratigraphic Database, Precision Stratigraphy Associates. http://precisionstratigraphy.com/CRET1CHRONOSTRATIGRAPHICDATABASE. $\underline{\mathrm{htm}}$

[14] Sageman, B.B., Rich, J., Savrda, C.E., Bralower, T., Arthur, M.A. and Dean, W.E. (1998) Multiple Milankovitch Cycles in the Bridge Creek Limestone (Cenomanian-Turonian), Western Interior Basin. In: Arthur, M.A. and Dean, W.E., Eds., Stratigraphy and Paleoenvironments of the Cretaceous Western Interior Seaway, USA, Society of Sedimentary Geology, Concepts in Sedimentology and Paleontology No. 6, 153-171. https://doi.org/10.2110/csp.98.06.0153 
[15] Elder, W.P. and Kirkland, J.I. (1985) Stratigraphy and Depositional Environments of the Bridge Creek Limestone Member of the Greenhorn Limestone at Rock Canyon Anticline near Pueblo, Colorado. In: Pratt, L.M., Kauffman, E.G. and Zelt, F.B., Eds., Fine-Grained Deposits and Biofacies of the Cretaceous Western Interior Seaway, Society of Economic Paleontologists and Mineralogists, Field Trip Guide Book No. 4, 122-134. https://doi.org/10.2110/sepmfg.04.122

[16] Leckie, R.M., Kirkland, J.I. and Elder, W.P. (1997) Stratigraphic Framework and Correlation of a Principal Reference Section of the Mancos Shale (Upper Cretaceous), Mesa Verde, Colorado. In: Anderson, O.J., Kues, B.S. and Lucas, S.G., Eds., Mesozoic Geology and Paleontology of the Four Corners Region, 48th Annual Field Conference of the New Mexico Geological Society, Albuquerque, NM (NMGS), 163-216.

[17] Cobban, W.A., Ireneusz, W., Obradovich, J.D. and McKinney, K.C. (2006) A USGS Zonal Table for the Upper Cretaceous Middle Cenomanian-Maastrichtian of the Western Interior of the United States Based on Ammonites, Inoceramids, and Radiometric Ages: U.S. Geological Survey Open-File Report 2006-1250, 45 p. 